\title{
Employing Microbes and Enzymes for Lignocellulosic Biomass Conversion to Energy
}

\author{
Lakshmi Pathak and Kavita Shah* \\ Institute of Environment and Sustainable Development, Banaras Hindu University, Indiaa
}

Submission: February 06, 2017; Published: July 28, 2017

*Corresponding author: Kavita Shah, Institute of Environment and Sustainable Development, Banaras Hindu University, Varanasi-221005 (U.P), India, Tel: +91-542-2366297/09450955423; Fax:+91-542-2366711; Email: csshahin@yahoo.co.in/kavitashah@bhu.ac.in

\begin{abstract}
In this review potential of biomass waste for energy generation and policy by Government of India is discussed. Renewable energy contributes approx. $13-14 \%$ of total energy generation out of which $12.83 \%$ energy is generated using biomass. India has surplus forest and agricultural area comprising 500 million metric tons of biomass every year with total biomass energy generation capacity of $18000 \mathrm{MW}$. At present $4845 \mathrm{MW}$ energy is generated including energy from cogeneration. It can be concluded that India has huge potential for conversion of available biomass wastes into energy. Among biomass wastes wood residues, forest remnants, agricultural residues and solid wastes have potential for energy generation on large scale with proper waste management. Calorific value of wood, sugarcane baggases, wheat and barley straw are nearby coal therefore, they can substitute coal for energy generation and helping in reduction of greenhouse gases. Lignocellulosic content of biomass wastes creates problem in its processing into fermentable sugars making bio fuel generation more expensive and harsh pre-treatment's. The role of biotechnology and potential of various enzymes and microorganisms for lignocellulose degradation has been briefly discussed. Cellulosomes from S. cerevisiae and B. subtilis; expansin and swollenin enzymes from T. reseei and A. fumigatausare identified to have cellulase activity. The paper suggests that though the numerous enzymes, microbial and fungal strains has been identified but research on identification of new enzymes still required which may provide better solutions for large scale pre-treatment of biomass.
\end{abstract}

Keywords: India; Lignocelluosic biomass; Biomass waste; Policy; Enzymes

Abbreviations: MW: Megawatt; GJ: Giga Joules; MSW: Municipal Solid Waste; CV: Calorific Value

\section{Introduction}

India is one of the fastest growing economies in the world endowed with abundant renewable energy resources and tremendous achievements in food production from "ship to mouth" from 1960 s. Currently $70-80 \%$ primary energy requirements of the country are fulfilled by the conventional resources, majorly coal and oil which are limited, non-renewable and polluting. On the other hand shares of energy generation from renewable resources like solar, wind, hydropower and biomass is around $13-14 \%$, which are indigenous, nonpolluting and virtually inexhaustible [1]. Energy consumption from biomass is in practice in India from ancient time mainly in form of cow dung cake, firewood, husks etc., but direct use of biomass for heating purpose is not safe and produces lots of smoke and ash which has harmful effect on health and polluting environment [2].
Biomass is defined as organic matter derived from water based vegetation, aquatic plants, energy crops, by products of agriculture, food and agro industries waste, municipal solid waste etc. stored in chemical energy which are broken by combustion or decomposition to release electrical or heat energy [3]. The potential of biomass as energy source has been explored from past some years and different biomass residues and wastes are utilized for energy generation. But these alternative use of biomass has created the problem of availability of food and land for agriculture for example corn, soybean and some other edible crops are utilised as energy source in western countries. The Indian approach to bio fuels, in particular, is somewhat advantageous as it is based solely on non-food feed stocks to be raised on degraded or wastelands that are not suited to agriculture, thus avoiding a possible conflict of fuel vs. food security faced by other countries [4]. Therefore, biomass wastes 
can be a possible and potential feedstock for biomass power production but the main hurdle is lingo-cellulosic components which needs pre-treatment with biological agents and their enzymes facilitating thermo-chemical or biochemical process easier to produce bio fuels.

In this paper potential of biomass waste and its properties for energy generation is identified. The installed capacity and policy regarding biomass power of India is discussed. The role of biotechnology and potential of various enzymes and microorganisms for the conversion of lingo-cellulosic biomass waste into energy is the notable portion of this communication.Installed biomass capacity of India and policy

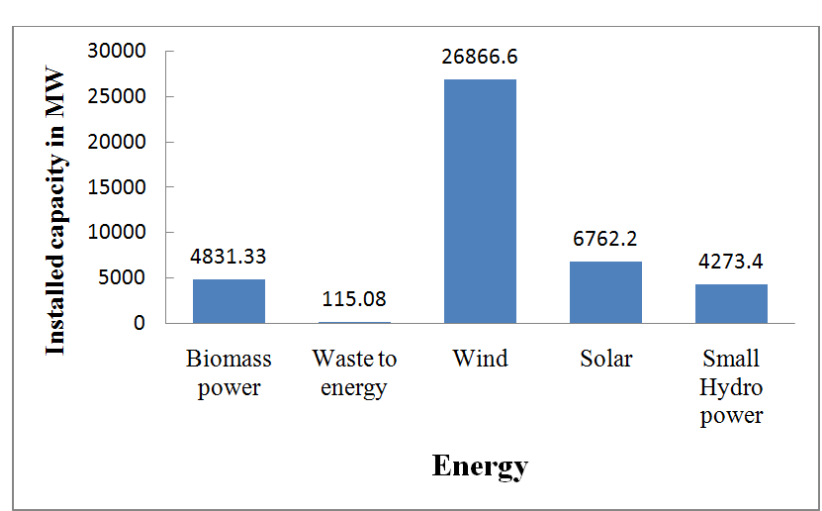

Figure 1: Total installed capacity biomass power and other renewable till 2016 [6].

The current biomass potential of India estimated by government of India is about 500 million metric tonnes per year. Biomass availability from agricultural and forestry biomass residues is 120-150 million metric tonnes per annum corresponding to potential of about 18,000MW [5]. Figure 1 shows the total installed capacity of biomass power and other renewable power [6]. Data shows that waste to energy generation is very low and therefore more opportunities of research lie for accelerating energy in this area. About $7000 \mathrm{MW}$ additional power could be generated through baggases based cogeneration in the country's 550 sugar mills. 500 biomass power and cogeneration projects aggregating to $4760 \mathrm{MW}$ capacity have been installed in 2015-16 for feeding power to the grid. In addition, 30 biomass power projects and 70 Cogeneration projects aggregating to about $1150 \mathrm{MW}$ are under various stages of implementation [5]. Some states have taken leadership position in implementation of baggases cogeneration projects are Andhra Pradesh, Tamil Nadu, Karnataka, Maharashtra and Uttar Pradesh. Indian biomass energy generation policy is based on growing of nonedible crops, oilseeds and molasses on degraded and marginal lands for production of biodiesel and bioethanol. An indicative target of $20 \%$ blending of bio fuels, both for biodiesel and bioethanol, by 2017 is proposed. Concessional excise duty of $16 \%$ is exempted on plant and machinery for production of biodiesel or bioethanol, as well as for engines run on bio fuels for transport, stationary and other applications, if these are not manufactured indigenously and no other central taxes and duties are proposed to be levied on bio fuel. Country's energy policy aims at efficient, secured and environment friendly approach but sadly proper implementation is lacking as well as not giving that much importance to biomass as required and practiced by other countries.

\section{Different types of biomass wastes}

Most Indian states and districts have access to one or another form of biomass supply and often in large quantities. Biomass feed stocks available as co-products from farms, forests, processing plants and municipal treatment plants are normally limited in the total volume available depending on population, size and scale of the source. Various biomass wastes classified depending upon the source of their origin below:

\section{Agricultural wastes}

India has vast agricultural land area therefore massive stalks, husks and other crop residues obtained after processing of agricultural crops. They are of two type's primary and secondary residue. Bio residue assembled at time of harvesting in the field like rice straw etc is collectively referred as primary residue which is mainly used to feed animals so cant 'be used much for energy generation and residues obtained after processing of crops like rice husks and baggases are termed as secondary source which are in practice for energy applications [7]. Among several agricultural feed stocks bajra, cotton, groundnut, coconut, jowar, maize, sugar cane, wheat and paddy have massive biomass potential ranging from 15,000 to 1.5 lakh (kt/yr) [1,7].

\section{Industrial wastes}

Discharge from paper, pulp, packaging, breweries and manufacturing industries generate problem of water and soil pollution causing health problems and unpleasant odors. These wastes can be used for generating energy and stabilizing wastes.

\section{Food and solid wastes}

Rejected food items like breads, vegetables, remnant food of hotels and kitchen, stale foods and other not used vegetable and fruit scraps from confectionaries can be an aerobically digested for biogas generation and landfill gases generated from disposed off dumps [1,8].

\section{Animal wastes and sewage}

Animal wastes from ancient ages are used as manure because they are mainly composed of organic matter, moisture and some other residues. These wastes are an aerobically or aerobically digested for production of methane and maintaining proper sanitation [9]. Sewage is similar to other animal waste stabilised from sewage treatment plant can also act as a source of biomass energy. 


\section{Municipal solid wastes (MSW)}

$80 \%$ of total municipal solid waste in India is composed of paper and plastics collected each year in millions of tonnes. The problems of their dumping and health problems related to them are always in news. MSW can be converted into energy either by direct combustion or by anaerobic digestion. The organic fractional part of MSW can be treated in high rate biomass digester to obtain biogas or methane can be generated at landfill sites [10].

\section{Forest wastes}

Leaves, twigs, barks, logs, chips, processed sawdust etc are few examples of forest waste which is abundant throughout world irrespective of seasons, boundaries and consumption pattern. In general, most agricultural residues and softwood contains more lignin than hardwood, therefore softwood is more recalcitrant to pre-treatment and bioconversion. Organic matter content and heating value of forest waste is larger than other types of biomass wastes after coal and peat [11].

\section{Properties of biomass}

Some inherent properties of the biomass that determine both the choices of conversion process and cost included for it:

Table1: Properties of selected material for energy generation $[1,3,11]$.

\begin{tabular}{|c|c|c|c|c|c|}
\hline Material & Cellulose (\%) & Hemicellulose (\%) & Lignin (\%) & $\begin{array}{c}\text { Moisture Content } \\
(\%)\end{array}$ & $\begin{array}{c}\text { Calorific Value(MJ/ } \\
\text { Kg) }\end{array}$ \\
\hline Soft wood & $35-40$ & $25-30$ & $27-30$ & 20 & $20-22$ \\
\hline Hard wood & $45-50$ & $20-25$ & $20-25$ & & \\
\hline Wheat straw & $33-40$ & $20-25$ & $15-20$ & 16 & $15-18$ \\
\hline Rice husk & 35 & $25-35$ & $25-30$ & 8.6-10.5 & $13-16$ \\
\hline Barley Straw & 33 & 20 & 17 & 30 & $16-18$ \\
\hline Sugarcane baggase & 30 & 56 & 13 & 10-Aug & 20 \\
\hline Coal & - & - & - & 11 & $26-28$ \\
\hline MSW & - & - & - & $30-40$ & $12-0 c t$ \\
\hline
\end{tabular}

The amorphous and branched properties make hemicelluloses susceptible to biological, thermal, and chemical hydrolysis of their monomer compounds. After cellulose, lignin is the second most abundant organic compound in nature [14]. It is a large and complex aromatic and hydrophobic amorphous heteropolymer and is made of phenylpropane units such as coniferyl alcohol and sinapyl alcohol with hydroxyl, methoxyl, and carbonyl functional groups [15]. Lignin plays the role of cement for the cross-linking between cellulose and hemicellulose to form a rigid three-dimensional structure of the cell wall [16]. Water insoluble and optically inert property of lignin make it the most recalcitrant component of the plant cell wall and make it resistant to chemical and biological degradation.

\section{Moisture content}

Table 1 lists the moisture content of range of biomass materials which is affected by weather conditions at the time of harvesting. Sources of woody materials include residues left in

\section{Ligno-cellulosic content}

Ligno-cellulosic biomass, such as agricultural residues and energy crops is an abundant organic resource [12]. Large quantities of lingo-cellulosic residues accumulate from agricultural, forestry, municipal, and other activities. Lignocellulosic biomass mainly consists of three types of polymers: cellulose, hemicellulose, and lignin. Table 1 illustrates the lingocellulosic content of various biomass wastes. The carbohydrate components are fermentable after hydrolysis, which makes lingo-cellulosic biomass a suitable feedstock for bioenergy production. Cellulose is the main component of lingo-cellulosic cell walls. It is a linear polysaccharide polymer of cellobiose strongly linked via $\beta-1,4$ glycosidic linkages. Cellulose chains are interlinked by hydrogen bonds and vander Waals forces, resulting in high tensile strength microfibrils [13]. This complicated structure renders cellulose resistant to biological and chemical attacks. In comparison to cellulose, hemicelluloses are branched heterogenic polysaccharides of various pentoses, hexoses and acids like glucuronic acid and galacturonic acid. Short and branched chains of hemicelluloses build a network with cellulose microfibrils and interact with lignin, rendering the cellulose hemicellulose lignin matrix extremely rigid.

natural forest, forestry wastes, such as sawdust from sawmills, wood chips and branches from dead trees, and cultivated short rotation energy forest plantations utilizing several fast growing tree species. Woody residues have low moisture content therefore forest wastes are more suitable for conversion into energy generation [11].

\section{Calorific value (CV)}

The total energy content or heat released when the fuel is burnt in air is termed as calorific value of material. The CV is calculated in terms of energy content per unit biomass or volume. The actual amount of energy required varies depending upon the conversion process and presence of moisture in biomass wastes. Calorific values of biomass wastes in Table 1 shows that wood and sugarcane baggases have higher calorific value but rice husk and barley straw are also better options for energy generation [11]. High moisture content biomass undergoes wet conversion process for example sugarcane while, energy generation from 
dry biomass is mostly done through gasification, pyrolysis or combustion; some other factors like cellulose content, ash, alkali and trace components influence thermal conversion process and biochemical fermentation process and play role in determining the selection of type of biomass and conversion process [11].

Role of microbes and enzymes for pre-treatment of biomass wastes

Pretreatment of biomass with fungal and bacterial strains hydrolyse glycosidic linkages which is inexpensive and easy to operate. However, large-scale operation of the biological pretreatment leads to higher operational costs and large, sterile area is required to maintain the sterile conditions during the treatment process. Table 2 enlists some commonly used fungal, microbial and fungal pretreatment for conversion of lignocellulosic biomass into sugar. None of the process discussed are efficient enough to give $100 \%$ yield of reducing sugars from all types of bio wastes.

Table 2: Biological agents involved in lingo-cellulosic conversion of biomass [25-27].

\begin{tabular}{|c|c|c|c|c|}
\hline Biological Agents & Microbes/ Enzymes & $\begin{array}{c}\text { Feedstocks/ Biomass } \\
\text { Waste }\end{array}$ & Pretreatment Conditions & Results \\
\hline Microbial Consortium & $\begin{array}{l}\text { Clostridium thermocellum, } \\
\text { and mixture of fungi and } \\
\text { composting microbes }\end{array}$ & $\begin{array}{l}\text { Agricultural residuals: } \\
\text { cornstraw, corn stalks, } \\
\text { cotton stalks, cassava } \\
\text { residues andmanures }\end{array}$ & $\begin{array}{l}20-55^{\circ} \mathrm{C} \text { for } 12 \text {-20 days; } \\
\text { Autoclaving of feedstock } \\
\text { before inoculation; Aerobic } \\
\text { condition }\end{array}$ & $\begin{array}{c}\text { Methane yield by25- } \\
96.63 \%\end{array}$ \\
\hline Fungal Pretreatment & $\begin{array}{l}\text { White, brown and soft-rot } \\
\text { fungi e.g.Ceriporiopsis } \\
\text { subvermispora, Auricularia } \\
\text { auricula-judae, Trichoderma } \\
\text { reesei andbasidiomycete } \\
\text { fungi e.g. Ischnoderma } \\
\text { resinosum and Fomitella } \\
\text { fraxinea }\end{array}$ & $\begin{array}{l}\text { Agricultural residuals: } \\
\text { sweetchestnut leaves/hay } \\
\text { Hardwood: Japanese } \\
\text { cedarwood chip }\end{array}$ & $\begin{array}{c}\text { Agricultural residuals: } \\
\text { sweetchestnut leaves/hay } \\
\text { Hardwood: Japanese } \\
\text { cedarwood chip }\end{array}$ & $15 \%$ methane yield \\
\hline $15 \%$ methane yield & $\begin{array}{l}\text { Laccase; pectinase; } \\
\text { mixture of cellulose } \\
\text { and hemicellulases / } \\
\beta \text { glucosidase; crude } \\
\text { Trichoderma enzyme } \\
\text { complex }\end{array}$ & $\begin{array}{l}\text { Agricultural residuals: } \\
\text { Sugarbeet pulp, spent hops, } \\
\text { andmanure biofibers } \\
\text { MSW: pulp and paper } \\
\text { Grass: jose tall wheatgrass }\end{array}$ & $\begin{array}{c}37^{\circ} \mathrm{C} \text { for } 4-24 \mathrm{~h} ; \text { Aerobic/ } \\
\text { anaerobic }\end{array}$ & $\begin{array}{c}\text { Approx. } 34 \% \text { increase of } \\
\text { methane yield }\end{array}$ \\
\hline
\end{tabular}

Group of enzymes that degrade cellulose, hemicellulose and lignin are cellulases, $\beta$-glycosidases, esterases, lyases, laccases and manganese peroxidases [17]. Laccase is a multicopper oxidase and can catalyze free radicals-mediated reactions that degrade lignin [18]. Manganese peroxidase oxidizes Mn2+ into Mn3+ by hydrolysis of hydrogen peroxide which is a powerful oxidant that degrades lignin. Cellulose degradation is achieved by synergistic action of three classes of hydrolytic enzymesendo-(1,4)- $\beta$ glucanase(endocellulase), cellobiohydrolase (exocellulase), and $\beta$-glucosidase.Whereas, hemicellulose degradation is achieved by actionof hydrolytic enzymes such as endo-xylanases, endo- $\alpha$ Larabinase,endo-mannanase, $\beta$-galactosidase, and $\beta$-glucosidases, respectively [19].

Biotechnological interventions used for identification of cellulosomes are arrays of multiple cellulase, hemicellulose and cohesion proteins bound to structural scaffolds on the microbial surface $[20,21]$. Recombinant cellulosomes are prepared and transplanted to other industrially useful organisms, such as $S$. cerevisiae and B. subtilis for synergistic breakdown of lignocellulosic biomass [22,23]. In the same way CIP proteins found in T. reseei likely to act on hemicellulose and lignin content because of their esterase activity [24]. Expansin and swollenin enzymes from T. reseei and A. fumigatausare identified to have cellulase activity [25].

\section{Conclusion}

India has large agricultural and forest area comprising about 500 million metric tons of biomass availability per year. In India total biomass power generation capacity is $18000 \mathrm{MW}$. 500 biomass power and cogeneration projects aggregating to 4760 MW capacity have been installed in 2015-16 for energy generation. The present study suggests that India has large potential for energy generation from biomass waste like, agricultural residues, forest remnants and municipal solid waste. The growing demand for liquid fuel accelerates the research in the areas of development and exploitation of cellulosic raw materials for improving energy generation from biomass wastes. Ligno-cellulosic content of biomass wastes renders its processing into fermentable sugars and bio fuel generation ends in expensive and harsh pretreatments. One major point that emerges out that combination of two or more biological processes is proven to be more efficient when compared with single pretreatment process. Improved analytical techniques and additional basic knowledge on the interrelationship among the major cell wall components, hemicellulose, lignin, pectin, and cellulose may be an important step toward improvement of energy generation.

Though the numerous enzymes has been identified significantly in recent years but research on new enzymes still 
required which may provide better solutions to this problem and give guidance as to how enzymes can be better applied to a variety of industrial processes. Microbiological interventions are required for identification of new enzymes from Actinomyces and Streptomyces genera which have more potential for degradation of lingo-cellulosic components. Emerging technologies are required for development of industrial processes for bulk and cost effective production of enzymes and development of processes and bio digesters where biomass waste could be treated in a single run. For environmental protection to become reality it is important for India to use and develop efficient biotechnological tools for treatment of biomass wastes.

\section{References}

1. Kumar A, Kumar N, Baredar P, Shukla A (2015) A review on biomass energy resources, potential, conversion and policy in India. Renewable and Sustainable Energy Reviews 45: 530-539.

2. Ezzati M, Kammen DM (2001) Indoor air pollution from biomass combustion and acute respiratory infections in Kenya: an exposureresponse study. The Lancet 9282: 619-624.

3. McKendry P (2002) Energy production from biomass (part 2): overview of biomass. Bioresour Technol 83(1):37-46.

4. Government of India. Ministry of New \& Renewable Energy. National policy on Biofuels.

5. Ministry of New and Renewable Energy. $11^{\text {th }}$ Five year plan: Annual report.

6. www.cea.nic.in/reports/monthly/installedcapacity/2016/installed_ capacity-03.pdf/

7. Murali S, Shrivastava R, Saxena M (2008) Quantification of agricultural residues for energy generation-a case study. J Inst Public Health Eng 3: 27 .

8. Reddy AKN (1995) The blessing of the commons. Energy Sustainable Dev II 2(1): 48-50.

9. Varshney R, Bhagoria JL, Mehta CR (2010) Small scale biomass gasification technology in India-an overview. J Eng Sci Manage 3: 33 40.

10. Zafar S (2009) Biomass wastes, alternative energy. eMagzine- Alt Energy Mag.com.

11. McKendry P (2002) Energy production from biomass (part 1): overview of biomass. Bio resource technology 83(1): 37-46.

12. Limayema A, Ricke SC (2012) Progress in Energy and Combustion Science 38(4): 449-467.
13. Mielenz JR (2001) Ethanol production from biomass: technology and commercialization status. Curr Opin Microbiol 4(3): 324-329.

14. Girio FM, Fonseca C, Carvalheiro F, Duarte LC, Marques S, et al. (2010) Hemicellulose. Bioresour Technol 101(13): 4775-800.

15. Stamatelatou K, Antonopoulou G, Ntaikou I, Lyberatos G (2012) The effect ofphysical, chemical, and biological pretreatments of biomass on its anaerobicdigestibility and biogas production. In: Mudhoo A (Ed.), Biogas production: pre treatment methods in anaerobic digestion. $\mathrm{NJ}$, Hoboken: John Wiley \& Sons Inc, USA, pp. 55-90.

16. Palmqvist E, Hahn-Hägerdal B (2000) Fermentation of lignocellulosichydrolysates, II:inhibitors and mechanisms of inhibition. Bioresour Technol 74(1): 25-33.

17. Zheng Y, Zhao J, Xu F, Li Y (2014) Pretreatment of lignocellulosic biomass for enhanced biogasproduction. Progress in Energy and Combustion Science 42: 35-53.

18. Eggert C, Temp U, Eriksson KE (1997) Laccase is essential for lignindegradation by thewhite-rot fungus Pycnoporuscinnabarinus. FEBS Lett 407(1): 89-92.

19. Shallom D, Shoham Y (2003) Microbial hemicellulases. Curr Opin Microbiol 6(3): 219-228.

20. Ding SY, Xu Q, Crowley M, Zeng Y, Nimlos M, et al. (2008) A biophysical perspective on the cellulosome: new opportunities for biomass conversion. Curr Opin Biotechnol 19(3): 218-227.

21. Bayer EA, Lamed R, Himmel ME (2007) The potential of cellulases and cellulosomes for cellulosic waste management. Curr Opin Biotechnol 18(3): 237-245.

22. Tsai SL, Goyal G, Chen W (2010) Surface display of a functional minicellulosome by intracellular complementation using a synthetic yeast consortium and its application to cellulose hydrolysis and ethanol production. Appl Environ Microbiol 76: 7514-7520.

23. Anderson TD, Robson SA, Jiang XW, Malmirchegini GR, Fierobe HP, et al. (2011) Assembly of minicellulosomes on the surface of Bacillus subtilis. Appl Environ Microbiol 77(14): 4849-4858.

24. Foreman PK, Brown D, Dankmeyer L, Dean R, Diener S, et al. (2003) Transcriptional regulation of biomass-degrading enzymes in the filamentous fungus Trichodermareesei. J Biol Chem 278(34): 3198831997.

25. Saloheimo M, Paloheimo M, Hakola S, Pere J, Swanson B, et al. (2002) Swollenin, a Trichoderma reeseiprotein with sequence similarity to the plant expansin, exhibits disruption activity on cellulosic materials. Eur J Biochem 269(17): 4202-4211. 
Your next submission with Juniper Publishers will reach you the below assets

- Quality Editorial service

- Swift Peer Review

- Reprints availability

- E-prints Service

- Manuscript Podcast for convenient understanding

- Global attainment for your research

- Manuscript accessibility in different formats ( Pdf, E-pub, Full Text, Audio)

- Unceasing customer service

Track the below URL for one-step submission https://juniperpublishers.com/online-submission.php 